\title{
Taxonomic implications of the residual colour patterns of ampullinid gastropods and their contribution to the discrimination from naticids
}

\author{
Bruno Caze, Didier Merle, Mathieu Le Meur, Jean-Michel Pacaud, Daniel Ledon and Jean-Paul Saint \\ Martin
}

Acta Palaeontologica Polonica 56 (2), 2011: 329-347 doi: http://dx.doi.org/10.4202/app.2009.0084

The diversity of residual colour patterns is revealed for the first time in the European fossil Ampullinidae. The colour patterns were studied under Ultraviolet (UV) light in approximately 3100 specimens belonging to 83 species, 12 genera (Ampullina, Globularia,

Crommium, Amaurellina, Pachycrommium, Amauropsina, Ampullonatica, Eocernina, Ampullinopsis, Vanikoropsis, Pictavia, and Ampullospira) and three subgenera (Globularia, Deshayesia, and Cernina within the genus Globularia). Forty-six Cainozoic species revealed residual colour patterns and 29 of them, belonging to six genera (Ampullina, Globularia, Crommium, Amaurellina, Pachycrommium, Amauropsina), are described herein as examples representing the entire diversity of the encountered colour patterns. These patterns are most diverse during the Middle Eocene coincident with the period of highest taxonomic diversity of the Ampullinidae. Four basic classes, regarded as containing possible homologous colour patterns in terms of pigments incorporation modalities, are proposed. Class I, a fluorescent wide diffuse area or spiral stripes, occurs in most of the species, while the three others are more peculiar. Class II, fluorescent axial zigzagging stripes, Class III, fluorescent axial to slightly opisthocline stripes or segments, and Class IV, fluorescent patches forming axial segments by coalescence, allow an easy distinction between the genera Globularia, Pachycrommium, and three peculiar species of Ampullina. The bauplan of the colour patterns revealed in Globularia is very similar to that of the single extant species, Globularia (Cernina) fluctuata. This supports the view of previous authors who classified them in the same genus. Furthermore, at the family level, the peculiar residual patterns belonging to classes II, III, and IV have not been observed in naticid gastropods. Thus our results for the Cainozoic fossil record are consistent with the conclusions based on anatomy and feeding habits, namely that ampullinid gastropods, regarded for a long time as belonging to the family Naticidae, constitute a family apart.

Key words: Ampullinidae, Naticidae, residual colour patterns, taxonomy, shell character, evolution, Cainozoic, Europe.

Bruno Caze [bruno.caze@mnhn.fr], Didier Merle [dmerle@mnhn.fr], Mathieu Le Meur [m.lemeur@hotmail.fr], Jean-Michel Pacaud [pacaud@mnhn.fr], Daniel Ledon 
[dnledon@yahoo.fr], Jean-Paul Saint-Martin [jpsmart@mnhn.fr], Muséum National d'Histoire Naturelle, Département Histoire de la Terre, Centre de Recherches sur la Paléobiodiversité et les

Paléoenvironnements (CR2P); UMR 7207 du CNRS. 8, rue Buffon, CP 38, F-75005 PARIS (France).

This is an open-access article distributed under the terms of the Creative Commons Attribution License (for details please see creativecommons.org), which permits unrestricted use, distribution, and reproduction in any medium, provided the original author and source are credited.

Forif Full text $(1,013.7 \mathrm{kB})$ ।

Fof Supplementary file $(17.9 \mathrm{kB})$ 